\title{
Translation Method USEd in Deli Malay \\ and Serdang Malay Folklores From \\ INDONESIAN TO ENGLISH
}

\author{
RIA RESTIKA ${ }^{1}$, MASITOWARNI \\ SIREGAR $^{2}$, LidIMAN SAHAT M SINAGA ${ }^{3}$ \\ ${ }^{123}$ UNIVERSITAS NEGERI MEDAN
}

\begin{abstract}
This study aimed to determine the many types of translation methods, how they were employed in the translation of the folklores "Deli Malay" and "Serdang Malay" from Indonesian to English, and why the translators used the prevailing types in these folklores. The descriptive qualitative method was used to perform this research. The data was gathered from a folklore book and an interview with the folklores' translator. Descriptive qualitative research is the method used to analyze the data. The findings of this study revealed that literal translation accounted for 39 sentences (16\%), faithful translation accounted for 23 sentences (9\%), semantic translation accounted for four sentences (2\%), adaptation translation accounted for seven sentences (3\%), free translation accounted for 158 sentences (64\%) and communicative translation accounted for 16 sentences (6\%). A total of 247 sentences were extracted from the data. Because he did not follow any theories or methods of translation when translating the texts, the translator utilized free translation as the dominating method. Instead, he evaluated the translations' target audience, youngsters, and made them acceptable and simple to understand.
\end{abstract}

Keywords: Translation, Translation Method, Folklores 


\section{INTRODUCTION}

Language is a system that connects thoughts that cannot be heard, seen, or touched with sounds, letters, manual signs, or tactile symbols (Gerald and James, 2010:5). Language has been critical in terms of communication to contribute their ideas, especially in this globalization era where communication is very needed to get many kinds of information.

In this era, many kinds of information are informed in English, such as books, magazines, journals, and articles. Many English texts are translated into Bahasa, and to fulfill the demand of international language, many texts are translated into English, while English and Bahasa have different cultures which influence the language used. Therefore, the process of Translation is required.

The Translation is known as an effort to transfer messages from one language called source language (SL) into another language called target language (TL). As proposed by Newmark (1988: 5), Translation is the process of converting the meaning of a text into another language in the manner intended by the author. The basic objective of translation, according to Taber (in Shifa, 2013: 5), is to make messages initially within one language available to others who know his native language.

In translation activity, two kinds of Translation can be done: translating non-literary text such as articles, textbooks, journals, and literary text such as short stories, poetry, and folktales. Folklore is included in literary works, so this study is focused on literary Translation.

In this study, the researcher is interested in analyzing the translation method used in Folklores. The translation method chosen as the study is because the translation method relates with the Translation result in translator's diction used in translating the folklores and to get a deeper understanding about Translation and cultural, literary works.

The researcher chose Deli Malay and Serdang Malay folklores as the object of this study because the folklores tell the readers about the legend and the origin of some districts around Deli Serdang at that time. In addition, the researcher wants to introduce the folklores to the reader because many people do not know the stories told in these folklores.

In this study, the researcher used Newmark's theory, which explains the translation method. Newmark (1988: 45) explores that there are eight types of translation method which is used in the process of Translation, are word- for- word translation, literal translation, faithful translation, semantic Translation, adaptation translation, free translation, idiomatic translation, and communicative Translation. 


\section{REVIEW OF LITERATURE}

Translating is an activity when translator transfers a language in a text form or source language (SL) to another language or target language (TL) accurately. According to Newmark (1988:5) translation is rendering the meaning of a text into another language in the way that the author intended the text.

Translation method is how to do translation to plan in translating process. Newmark (1988:46) explained eight methods of translation in two different perspectives. Each perspective provides four methods of translation. The first perspective provides:

a. Word for word translation is a method of translation which is used by the translator by translating the text word by word and keeps the structure of the target text similar.

b. Literal translation. In literal translation, the translator change the Source Language (SL) structure into the Target Language (TL) structure but the words are translated literally but not the structure like the word-for-word translation.

c. Faithful translation attempts to reproduce the precise contextual meaning of the original within the constraints of the TL grammatical structure.

d. Semantic translation. This method is almost the same as the faithful translation. The differences from this method are the semantic translation is more accurate (not keeping the lexis and the SL grammar that violate the TL norms), more flexible (allowing the translator intuitive work that based on the original meaning), and has aesthetic value (the natural and beautiful sound) than faithful translation.

While the second perspective provides:

e. Adaptation translation is known as the freest method. It means that the relation between language and culture to source language is very thin and the attachment is closer to the target language. Cultural elements contained in the source language are replaced with cultural elements that are closer and familiar to the target reader.

f. Free translation reproduces the matter without the manner, or the content without the form of the original. Usually it is a paraphrase much longer than the original, a so-called 'intra lingual translation' often prolix and pretentious, and not translation at all.

g. Idiomatic translation attempts to deliver the message of the source text. In this translation method, the translator uses the colloquialism and equivalent in the TL that may have different meaning in the SL, therefore it can give the wrong 
meaning of the source text.

h. Communicative translation. This method attempts to deliver the exact meaning of the source text considering the TL readers according to their level of age, class, sex and education, so the translation product can convey the meaning or the message of the source language communicatively.

\section{RESEARCH METHODOLOGY}

This research was conducted by using descriptive qualitative research. Kothari (2004:3) states that qualitative research is concerned with qualitative phenomenon that relating to or involving quality or kind. This research was focused on analyzing the method used by the translator in the translation of the folklores "Deli Malay and Serdang Malay". Furthermore, the data will be analyzed based on the translation method by using Newmark's theory (1988). Finding and explaining the reason why the method is dominantly used in the translation of the folklores from Indonesian to English.

\section{DATA AND DATA ANALYSIS}

The data of this research were the narratives and dialogues of the folklores "Deli Malay and Serdang Malay" from Indonesian to English. There are total 247 sentences, and the data have been classified into the types of translation method based on Newmark's theory. From these 247 sentences, it was found that there were six out of eight types of translation methods used by the translator in translating the folklore, they are; 1) Literal Translation, 2) Faithful Translation, 3) Semantic Translation, 4) Adaptation Translation, 5) Free Translation, and 6) Communicative Translation.

\section{Types of Translation Method Used}

Table 4.1 shows the findings of the types of translation method used in the folklore "Deli Malay and Serdang Malay" from Indonesia into English.

Table 4.1 Types of Translation Method Used

\begin{tabular}{|l|l|l|l|}
\hline NO & Translation Method & Number & Frequency \\
\hline 1 & Word-for-word Translation & 0 & $0 \%$ \\
\hline 2 & Literal Translation & 39 & $16 \%$ \\
\hline 3 & Faithful Translation & 23 & $9 \%$ \\
\hline 3 & Semantic Translation & 4 & $2 \%$ \\
\hline
\end{tabular}




\begin{tabular}{|l|l|l|l|}
\hline 4 & Adaptation Translation & 7 & $3 \%$ \\
\hline 5 & Free Translation & 158 & $64 \%$ \\
\hline 6 & Idiomatic Translation & 0 & $0 \%$ \\
\hline 7 & Communicative Translation & 16 & $6 \%$ \\
\hline & Total & 247 & $100 \%$ \\
\hline
\end{tabular}

\section{The Use of Translation Method}

It was found that there were six out of eight types of translation methods (Literal, Faithful, Semantic, Adaptation, Free, and Communicative translation) were used based on the text in the folklores "Deli Malay and Serdang Malay" as follows:

\section{a. Literal Translation}

SL: Kekuasaan Langka Pura ini meliputi Deliserdang,

Percut, sampai juga ke daerah Deli, dan Medan.

TL: Its domination including Deliserdang, Percut, Deli

land and Medan.

The sentence in the Target Language is translated by using literal translation method. The word its which means itu (kepunyaan) in Indonesian is not available in the SL sentences. The translator does not rewrite kekuasaan Langka Pura, but the translator replace Kekuasaan Langka Pura into its. The literal translation is still out of the context, almost the same as word for word translation. This method can also be used as the first step for doing translation. The differences in grammatical construction in Source Language which seeks to be changed to approach the grammatical construction of Target Language.

\section{b. Faithful Translation}

SL: Masa itu, Pulau Berayun masih berupa kedatuan 
TL: At that time Pulau Berayun was still kedatuan

(province)

The sentence in Target Language is translated by using faithful translation method. The words Masa itu, Pulau Berayun masih berupa kedatuan translated into At that time, Pulau Berayun was still kedatuan (province). The translator keeps faith in the translations by translating it becomes At that time, Pulau Berayun was still kedatuan (province) in target language and didn't improve the structure, add or less some other words. Only kedatuan which translated become province as it is adjusted to the TL.

c. Semantic Translation

\section{SL: Tempat itu biasa dijadikan sebagai arena bertarung oleh}

orang-orang ingin melaga ilmu

TL: This was an area where the people usually fought and had a war.

The sentence in Target Language is translated by using semantic translation method. Semantic translation is different from faithful translation, because it has to take into the aesthetic elements (beauty sounds) of the source language text by compromising meaning as long as it is within reasonable limits. In addition, the words that contain little cultural content can be translated as neutral words or functional terms. When compared to faithful, semantic is more flexible. The words melaga ilmu in SL is translated into had a war in the TL. If the translator translated the words melaga ilmu in literal is competing knowledge but the translator translated this phrase by using his creativity by adding aesthetic value into the TL.

\section{d. Adaptation Translation}

SL: Tapi alangkah malang nasib mereka. rumah orang

tua mereka sudah porak-poranda rata dengan tanah. 43 
TL: As they arrived home, they found their house was

demolished.

The sentence in the source language is translated by using the adaptation translation, because the translator translated the sentence with the converted the culture the SL into TL. In the sentence the phrase porak-poranda rata dengan tanah is translated become demolished. The phrase porak-poranda rata dengan tanah is accepted in Indonesian, and the word demolished is accepted in English. If the translator translated the phrase porak-poranda rata dengan tanah by using literal translation become ravaged flat on the ground. Will cause ambiguity.

\section{e. Free Translation}

SL: Dulu Deliserdang bersatu tiada pula berbelah-belah.

TL: The region of Deli Serdang was so large that no other 10

rules wanted to separate their area from it.

The sentence in the source language is translated by using free translation method. Free translation is rewriting without seeing the original form. Usually a paraphrase that can be shorter or longer than the original. In this sentence it is clear that the translator makes the sentence longer than the original and the meaning in the SL into TL is not interrelated. Because of the reason, it would make this translation includes into free translation method. 


\section{f. Communicative Translation}

\begin{tabular}{|l|l|}
\hline SL: Begitulah ceritanya. & \multirow{2}{*}{76} \\
TL: That is the story of Panglima & \\
Denai. & \\
\hline
\end{tabular}

The sentence in the source language is translated by using communicative translation method. The translator translated the source language begitulah ceritanya from the source language with communicative way that the translator deliver the meaning and message from the source language becomes That is the story of Panglima Denai in the target language. Because of the reason, it would make this translation included into communicative translation method.

\section{The Rreason Why the Translator mostly Used Free Translation}

After the researcher analyzed the translation method used in the folklore, it can be seen that the most dominant type of Translation method used by the translator in the folklore "Deli Malay and Serdang Malay" is Free Translation which is found in 158 sentences, from the total 247 sentences. To answer the research question number 3, the researcher interviewed the translator, his name is Yolferi.

Table 4.2 Translator Interview

No Questions $\quad$ Answers

1. Sudah berapa lama Bapak menjadi penerjemah disini (Balai Bahasa), Pak?

2. Apakah Bapak selalu menerjemah bukubuku fiksi saja, atau Bapak juga menerjemah buku non fiksi?
Saya menjadi penerjemah sejak awal saya bekerja disini. Sudah sekitar 10 tahunan.

Biasanya, saya hanya menerjemah bukubuku fiksi saja.

3. Sebelum menerjemahkan sebuah cerita, Pertama pasti saya baca dulu ceritanya, apa sajakah langkah awal yang Bapak saya cari tau dulu target produksi buku ini lakukan? lalu setelah itu, 
saya mulai menerjemahkan.

4. Apakah saat menerjemah buku Antologi cerita dari Melayu Deli dan Serdang ini, bapak mengikuti atau berpedoman pada metode penerjemahan, Pak?
Tidak, saya tidak melihat buku atau mengingat-ngingat teori yang ada, itukan bacaan saya waktu saya masih kuliah. Saat proses penerjemahan, yang saya lakukan adalah menyesuaikan kalimatnya saja, agar mudah diterima dan dipahami.

5. Setelah saya lakukan penelitian terhadap Ya saya juga tidak menyangka jika buku ini, metode yang paling dominan adalah free translation. Kenapa Bapak lebih banyak menggunakan metode ini, Pak? metode itulah yang dominan. Seperti

yang saya bilang tadi, saya hanya mengusahakan agar bahasa terjemahannya sesuai dengan anak- anak dalam arti mudah dipahami. Jadi, saya tidak terikat pada kata per-kata, ataupun struktur bahasa sumber dengan bahasa sasarannya. Yang terpenting adalah bahasanya mudah dipahami, dan pesannya tersampaikan. Itu saja 
After the researcher interviewed the translator, about the reason why the translator mostly used the

Free Translation, it is found that it happened because the translator did not translate the story based on particular theory or method exist in the translation theory when translating the "Deli Malay and Serdang Malay" Folklores.

\section{CONCLUSIONS AND SUGGESTIONS}

\section{Conclusions}

Based on the research findings found after analyzing the data, it can be concluded that:

(1) There were six out of eight types of translation method used by the translator in translating the folklore "Deli Malay and Serdang Malay" from Indonesian into English, they are : 1) Literal Translation, 2) Faithful Translation, 3) Semantic Translation, 4) Adaptation Translation, 5) Free Translation, and 6) Communicative Translation. It can be seen that the total of the sentences from the data were 247 sentences. The translator only used six translation methods out of eight translation methods based on Newmark's theory in the translation of the folklores "Deli Malay and Serdang Malay" from Indonesian into English, they are: Literal Translation (16\%), Faithful Translation (9\%), Semantic Translation (2\%), Adaptation Translation (3\%), Free Translation (64\%), and Communicative Translation (6\%) and Word for Word translation and Idiomatic translation are not used in the translation of these folkores.

(2) There were six out of eight types of translation method (Literal Translation, Faithful Translation, Semantic Translation, Adaptation Translation, Free Translation, and Communicative Translation) were used by the translator in translating the folklore "Deli Malay and Serdang Malay" from Indonesian into English, as follows; 1) Literal Translation in sentence number 31. The word its which means itu adalah in Indonesian is not available in the SL sentences. The translator does not rewrite kekuasaan Langka Pura, but the translator replace Kekuasaan Langka Pura into its. The literal translation is still out of the context, almost the same as word for word translation. This method can also be used as the first step for doing translation. 2) Faithful Translation in sentence number 7. The words Masa itu, Pulau Berayun masih berupa kedatuan translated into At that time, Pulau Berayun was still kedatuan (province). The translator keeps faith in the translations by translating it becomes At that time, Pulau Berayun was still kedatuan (province) in target language and didn't improve the structure, add or less some other words. Only kedatuan which translated become province as it is adjusted to the TL. 3) Semantic Translation in sentence number 17. The words melaga ilmu in SL is translated into had a war in the TL. If the translator translated the words melaga ilmu in literal is competing knowledge but the translator translated this phrase by using his creativity by adding aesthetic value into the TL. Semantic translation is different from faithful translation, because it has to take into the aesthetic elements (beauty sounds) of the source language text by compromising meaning as long as it is within reasonable limits. 4) Adaptation Translation in sentence number 43 . The sentence in the source language is translated by using the adaptation translation, because the translator translated the sentence with the converted the culture 
the SL into TL. In the sentence the phrase porak-poranda rata dengan tanah is translated become demolished. The phrase porak-poranda rata dengan tanah is accepted in Indonesian, and the word demolished is accepted in English. If the translator translated the phrase porak-poranda rata dengan tanah by using literal translation become ravaged flat on the ground. Will cause ambiguity. 5) Free Translation in sentence number 10. Free translation is rewriting without seeing the original form. Usually a paraphrase that can be shorter or longer than the original. In this sentence it is clear that the translator makes the sentence shorter than the original and the meaning in the SL into TL is not interrelated. Because of the reason, it would make this translation includes into free translation method. 6) Communicative Translation in sentence number 76. The translator translated the source language begitulah ceritanya from the source language with communicative way that the translator deliver the meaning and message from the source language becomes That is the story of Panglima Denai in the target language. Because of the reason, it would make this translation included into communicative translation method.

(3) The Free Translation method is the most translation method used by the translator.The reason why the translator used Free Translation method as the most dominant method in the translation of these folklores was because the translator did not use any approach and theory of translation, because the only thing he considered when translating the stories was the Readers which were children, so he produced the target language that was acceptable and easy to understand.

Therefore, the translator did not use word for word translation in the translation. To support this findings, in the previous research, in her study, Nasution (2017), she found that the dominant type of translation method is Free Translation. The folklore was also aimed for the Children. And Otava (2013:10) stated that every translation has an audience, and the better the translator knows the audience and is aware of it, the better are the chances of producing a good and usable translation.

\section{Suggestion}

Based on the conclusion, the suggestions are follows:

1. It is suggested that the students of English Department especially English Literature students should know how to analyze translation method in literary work such as drama, poetry, song, folklore, novel or act.

2. It is suggested that the teacher of the translation subject should explain more related to what method can be best used in translating every different kind of text before practicing to translate the text. the teacher should introduce the information of the cultural background of the text that the student will translate and use good grammar in translation

3. It is suggested that other researcher who are interested to continue this research, the object of the research should focus on novel, drama, poetry, song and act. Not only using Peter Newmark's theory but also another expert. 


\section{REFERENCES}

Bassnett, S. 1991. Translation Studies. London: Routledge.

Bell, R. T. 2005. Translation and Translating Theory and Practice. London. British Library Cataloguing in Publication Data.

Chaer, A. 1994. Linguistik Umum. Jakarta: Rineka Cipta.

Delahunty, Gerald P., and Garvey, James J. 2010. The English Language: From Sound to Sense. Perspective on Writing. Fort Collins, Colorado: The WAC Clearinghouse and Parlor Press.

Dundes, A. 1965. The Study of Folklore. Engelwood Cliff: N.J. Prentice Hall.

Eagleton, T. 2008. Literary Theory An Introduction Anniversary Edition. UK: BLACKWELL Publishing.

Fawcett, P. 1997. Translation and Language: Linguistic Theories Explained. Manchester: St Jerome Publishing.

Hatim, Basil and Ian, M. 1997. The Translator as Communicator. London: Routledge.

Imroatussholihat. I. 2012. The Analysis of Translation Method Used in Translating English Film's Script of “ICE AGE 3"innto Indonesian Language. Unpublished Paper. Bandung: STKIP Siliwangi Bandung.

Iranmanes, Z. October. 2013. Narative prose and Its Diffrent Types. Journal of Languages and Culture. Vol. 4(8), pp.125-131.

Kothari, C.R. 2004. Research Methodology: Methods and Technique. $2^{\text {nd }}$ Edition. New Age International Publisher: New Delhi.

Larson, M. L. 1984. Meaning Based Translation: A Guide to Cross-Language Equivalent. Lanham: University Press of America.

Misch. M. 2008. Teaching Folktales. Nordestedt: Books on Demand GMBH Munday, J., 2001.

Introducing Translation Studies. Theories and Applications.

London: Routledge

Nasution, N.S. Translation Method in Indonesian Folklore "Batu Menangis" Translated into English. Unpublished Paper. Medan : Universitas Negeri Medan.

Newmark, P. 1981. Approaches to Translation. Oxford: Pergamon Press.

Newmark, P. 1988. A Textbook of Translation. United Kingdom: Prentice Hall International (UK) Ltd

Otava, Anni. 2013. Focus on the Audience: Three Cases of User-Centered Translation. Online Paper: University of Tampere.

Prasmawati, M. I. 2016. An Analysis on Translation Method and Quality of Passive Voice 
in I AM NUMBER FOUR LEVEL. Unpublished Paper. Surakarta : Universitas Muhammadiyah Surakarta.

Robinson, Douglas (2003). Becoming a translator. $2^{\text {nd }}$ Ed. London: Routledge.

Rosyid, A. 2011. THE ANALYSIS OF THE ENGLISH-INDONESIAN TRANNSLATION METHOD IN A NOVEL “A STUDY IN SCARLET SHERLOCK HOLMES” BY SIR ARTHUR CONAN DOYLE. Unpublished Paper. Jakarta : State Islamiic University "Syarif Hhidayatullah".

Shifa, M. 2013. Translation Methods in "A WALK TO REMEMBER” Novel Translated into "KAN KU KENANG SELALU. Unpublished Paper. Semarang: UDINUS

Smith, C. 2015. Folklore and Children's Literature: A Content Analysis of the Grummond Children's Literature Collection. University of Southern Mississipi. Vol. 4, Issue 2.

Syafrizal, and Rohmawati, C. 2018. Translation Methods in " A WALK TO REMEMBER" Novel Translated into "KAN KU KENANG SELALU”. Journal of English Language Studies: Universitas Sultan Ageng Tirtayasa.

Tampubolon. S. 2016. Code Mixing in Mia Arsjad's Cinlok Accidentally in Love. Unpublished Paper. Medan: UNIMED

Timen, Farah A. A. 2015. An Analysis of Translation Methods for English Proverbs: Literal, Literary or Substitution. European Academic Research: Al Mustansiriya University

Yolferi, and Medtolia, J. 2018. Bunga Rampai Cerita Rakyat Melayu Deli dan Melayu Serdang. Sumatera Utara: Balai Bahasa

Yudha, D.W. 2013. Translation Methods Used in Three Chapters of “TANJUNG MAS SEBAGAI CENTRAL POINT PORT” Handbook. Unpublished Paper. Semarang: UDINUS. 